\title{
Educational platforms and ecosystems in digital economy
}

\author{
Natalia Usova*, Mikhail Loginov, and Elvira Nedorostkova \\ Russian Presidential Academy of National Economy and Public Administration, Ural Institute of \\ Management, 8 Marta Str., Ekaterinburg, Russia
}

\begin{abstract}
The article considers digital educational services market development on the basis of digital platforms. Research subject: financial market digitalization. Research purpose: to develop theoretical provisions of digital educational services. Research methods. In the course of the research such methods as analysis, grouping, comparison, and synthesis have been used. Results: 1. A specific approach to the categories of "digital educational platform" and "digital educational ecosystem (ecosystem-based higher education)" is proposed. 2. The classification criteria of digital platforms are systematized on various grounds and the "operation scale" criterion was added to the digital educational platforms classification. 3. The current market state is characterized and the latest innovations in the digital educational services are reviewed. 4. Risks of the platform-based and ecosystem-based higher education models development are revealed. Scientific novelty: the authors' specific approaches to the categories of "digital educational platform" and "digital educational ecosystem (ecosystem-based higher education)" are proposed, digital platforms classification criteria are systematized on various grounds, and the "functioning scale" criterion was added to the digital educational platforms classification.
\end{abstract}

\section{Introduction}

The higher education system has been undergoing the enhancement process for quite a long time, and since 2020, these transformations have been growing at a dramatic rate. The digital transformation of education system is in process and a new stage - platform-based education - is being developed.

The research purpose is to develop the theoretical framework of digital educational services.

This predetermined the objectives of the research.

First, to propose an authors' approach to categories illustrating digital educational platforms and ecosystems.

Second, to provide the system of the digital platforms on classification criteria on various grounds and to update the digital educational platforms classification.

\footnotetext{
* Corresponding author: nata-ekb-777@yandex.ru
} 
Next, to define the current market situation and provide an overview of the latest innovations in digital educational services.

The fourth oblective is to reveal the risks of the platform-based and ecosystem-based higher education models development.

\section{Materials and methods}

Considering that the issues of increasing the education system efficiency and competitiveness at the international level have long been a priority area, it is necessary to not only find directions for improvement, but also ensure their effective implementation.

The pandemic of Covid-19, the new coronavirus infection, acting as a "touchstone", made it possible to identify all the shortcomings and limits keeping back platform educational environment development.

In the course of the research, the authors used analysis, comparison, grouping methods.

The research is based on the scholarly works by: Anakhov S.V. [1], Anakhov D.S. [1], Aturin V.V. [2], Babkin A.V. [3], Velichko O.A. [10], Geliskhanov I.Z. [3], Dvoryadkina E.B. [4], Efimova E.G. [4], Keshelava A.V. [5], Loginov M.P. [6,7], Moga I.S. [2], Myslyakova, Yu.G. [9], Naydenko I.S. [10], Nedorostkova E.E. [7], Popova E.V. [11], Semenov A.I. [11], Smagulova S.M. [2], Smirnov E.N. [12], Usova N.V. [6,7,9], Khaet I.L. [5], Yudina T.N. [3].

\section{Resuls and discussion}

Addressing the issues of the platform-based education, it is important to note, that if the first stages are distinguished by installation and further modernization of computer classrooms, training to work in a digital space and with specialized software, currently, it is much easier for the present day school-leavers and students, who have all the neccessary skills, to work and communicate on various digital platforms than offline. If considered in a simplified form, in terms of marketing communications specifics, modern school-leavers and students can be divided into 2 target audiences. The first target audience is schoolleavers and students who prefer analog channels of interaction and traditional educational technologies. The second is school-leavers and students who support digital educational technologies. For them, the best option is to work on various platforms in the digital space, which largely impact educational process development. For example, one of the educational technologies is mind mapping, which aims at creative rethinking of theoretical material and presenting it in a structured form. Specifically, this technology can be used both in classroom without using digital technologies, and through special internet resources. Moreover, both options provide creative group work with the predetermined scope of material to be mastered by students in the course of the study process.

Modern school-leavers and students seek active self-improvement, creative selfexpression and have multitasking abilities to work using large amounts of information, which is their specific feature to be taken into account both when building marketing communications with potential students and educational process improvement.

In turn, modern teachers also have to act in a multitasking mode, at the same time, aiming at improving their efficiency.

In the framework of digital model of the national economy and under the influence of the pandemic of the new coronavirus infection Covid-19, the issues of not only the possibility of using digital educational resources and their development, but also of various digital platforms availability and transition to a digital educational ecosystem become relevant. 
Approaches to the categories of "digital educational platform" and "digital educational ecosystem" differ in research studies. From the authors' point of view, a digital educational platform is a digital space enabling the educational process participants to interact regardless of their territorial location.

In general, digital platforms can be classified by various accounts: operation scale, value component, focus of digital services provided, the platform specialization, available economic benefits, provided functionality development level, platform activities result, development level and focus provided. A detailed classification of digital platforms and their characteristics are presented in Table 1.

Table 1. Classification of digital platforms on various grounds [Compiled by the authors].

\begin{tabular}{|c|c|}
\hline $\begin{array}{c}\text { Types of } \\
\text { digital platforms }\end{array}$ & Characteristics \\
\hline \multicolumn{2}{|r|}{ Operation scale } \\
\hline National & $\begin{array}{c}\text { Digital platform developed and operating within one state. For } \\
\text { example, Qiwi }\end{array}$ \\
\hline Regional & $\begin{array}{l}\text { Digital platform operation in a particular region only. For example, } \\
\text { Asia, North America. Yandex, Odnoklassniki, GLONASS to name } \\
\text { a few. }\end{array}$ \\
\hline Global & $\begin{array}{c}\text { Digital platform not limited by national borders and users are } \\
\text { located all over the world. Take for example, PayPall, Instagram, } \\
\text { Facebook }\end{array}$ \\
\hline \multicolumn{2}{|r|}{ Value component $[12$, p.18] } \\
\hline Transaction platforms & Platforms aimed at facilitating seller-buyer interaction \\
\hline Integrated platforms & $\begin{array}{l}\text { Platforms combining elements of the transaction platform and } \\
\text { innovative platform. }\end{array}$ \\
\hline Innovative platforms & $\begin{array}{l}\text { Platforms bringing together developers of innovative technological } \\
\text { solutions, including innovative products and services. }\end{array}$ \\
\hline Investment platforms & $\begin{array}{l}\text { Platforms acting as a holding company and / or platform investor, } \\
\text { involving companies developing platform portfolio strategy. }\end{array}$ \\
\hline \multicolumn{2}{|r|}{ Focus of digital services provided } \\
\hline Aggregated platforms & Consolidating various services on one digital platform. \\
\hline Social platforms & Digital platforms providing communications services. \\
\hline Mobilization platforms & $\begin{array}{l}\text { Digital platforms allowing to from information picture of } \\
\text { interaction, for example, with clients. This information will furhter } \\
\text { provide for building a CRM system. }\end{array}$ \\
\hline Learning platforms & Digital platforms providing access to various learning materials. \\
\hline \multicolumn{2}{|r|}{ Platform specialization [3] } \\
\hline Social networks & $\begin{array}{l}\text { Online platforms for communicating, friends finding, creating } \\
\text { common interests groups, both professional or personal. }\end{array}$ \\
\hline Messengers & Platforms for online audio and video calls, and text messaging. \\
\hline Search engines & $\begin{array}{l}\text { Platforms used for quick access to the necessary information on the } \\
\text { Internet. }\end{array}$ \\
\hline Web browsers & $\begin{array}{c}\text { Platforms for processing search queries, page views, and web } \\
\text { document content. }\end{array}$ \\
\hline Videoplatforms & $\begin{array}{c}\text { Digital platforms for downloading and further viewing of video } \\
\text { materials. }\end{array}$ \\
\hline PC OS & $\begin{array}{l}\text { A set of programs interrelated and used to manage PC resources and } \\
\text { interact with users. }\end{array}$ \\
\hline
\end{tabular}


Continuation of table 1.

\begin{tabular}{|c|c|}
\hline Mobile OS & m for mobile devices, except for laptops. \\
\hline Online payment systems & $\begin{array}{c}\text { Digital platform for settlements with various participants (both } \\
\text { individuals and legal entities). }\end{array}$ \\
\hline Crowdfunding & $\begin{array}{l}\text { Digital platforms posting and promoting relevant projects on the } \\
\text { Internet with legal and financial support. Funds can be raised to } \\
\text { support startups, help victims of natural disasters, etc. One example } \\
\text { is when musicians can raise funds to record a studio album. }\end{array}$ \\
\hline Training & $\begin{array}{c}\text { Digital platform providing opportunities to get training in specific } \\
\text { disciplines or areas. }\end{array}$ \\
\hline Job hunting & Digital platforms for job search and recruiting. \\
\hline E-commerce & Digital platforms for purchasing goods. \\
\hline Passenger transportation & $\begin{array}{l}\text { Digital platform aimed at meeting the need tof travelling by car } \\
\text { (taxi or car rental). }\end{array}$ \\
\hline Residental rent & $\begin{array}{c}\text { Digital platforms providing access to a database of real estate } \\
\text { objects for rent or sale. }\end{array}$ \\
\hline Tourism and travelling & A digital platform enabling users to plan their trips. \\
\hline Coupons and discounts & $\begin{array}{c}\text { Digital platforms bringing together manufacturers of goods and } \\
\text { services which provide a certain percentage discounts, on condition } \\
\text { of having a coupon / discount on this platform for a limited period } \\
\text { of time. }\end{array}$ \\
\hline Civil services & $\begin{array}{c}\text { Digital platform giving opportunities to receive government } \\
\text { services via the Internet. }\end{array}$ \\
\hline
\end{tabular}

\section{Available economic benefits}

\begin{tabular}{|c|c|}
\hline Commercial & $\begin{array}{c}\text { Digital platforms designed to meet consumers' needs and demands } \\
\text { and to gain economic benefit from that. }\end{array}$ \\
\hline Non-commercial & $\begin{array}{c}\text { Digital platforms to meet consumers' needs and demands, but } \\
\text { without any profit derived }\end{array}$ \\
\hline \multicolumn{2}{|c|}{ Development degree of provided functionality [5] } \\
\hline Technological & Digital platforms providing access to IT resources and technologies. \\
\hline Functional & Digital platforms giving access to specialized tools. \\
\hline Infrastructural & Digital platforms providing access to digital infrastructure. \\
\hline Corporate & Digital platforms allowing for management processes optimization. \\
\hline Informational & Digital platforms providing informational access to the market. \\
\hline Marketplaces & $\begin{array}{c}\text { Digital platforms aimed at ensuring interaction of the parties by } \\
\text { providing access to the market. }\end{array}$ \\
\hline Sectoral & Digital platforms to optimize the participants interaction. \\
\hline Instrumental & $\begin{array}{c}\text { Digital platform with software and hardware solutions development } \\
\text { as a result. }\end{array}$ \\
\hline Infrastructural & $\begin{array}{c}\text { Digital platform where the outcome is IT service and information } \\
\text { essential for economic decision-making. }\end{array}$ \\
\hline Applied & $\begin{array}{c}\text { Digital platform with transaction as a result, fixng exchange of } \\
\text { goods / services between participants in a given market. }\end{array}$ \\
\hline Classification by Popova E.V., Semenov A.I. [11, p.235]
\end{tabular}

digital platforms providing

online business models implementation
Value chain participants manufacture and sell products online and interact with customers via online portals. 


\begin{tabular}{|c|c|}
$\begin{array}{c}\text { Continuation of table 1. } \\
\text { digital platforms } \\
\text { providing high-tech } \\
\text { products development }\end{array}$ & $\begin{array}{c}\text { Chain parties are involved in applied and scientific research, } \\
\text { scientific development creating intellectual property, which is a } \\
\text { competitive advantage of a particular company, group of companies } \\
\text { or a country in general. }\end{array}$ \\
\hline $\begin{array}{c}\text { digital platforms } \\
\text { providing } \\
\text { participants integration } \\
\text { by their specific goals } \\
\text { and needs }\end{array}$ & $\begin{array}{c}\text { Digital platforms as modern social networks, Internet forums and } \\
\text { communities, etc. }\end{array}$ \\
\hline $\begin{array}{c}\text { digital platforms } \\
\text { providing } \\
\text { interaction of participants } \\
\text { with public organizations } \\
\text { fulfilling government } \\
\text { assignments }\end{array}$ & $\begin{array}{c}\text { Digital platforms to provide public services for individuals and } \\
\text { legal entities and digital platforms ensuring interaction of } \\
\text { comercial and non-profit organizations with government agencies } \\
\text { in the framework of certain projects implementation. }\end{array}$ \\
\hline \multicolumn{2}{|c|}{\begin{tabular}{c} 
By development degree \\
\hline Online-store
\end{tabular}} \\
\hline Marketplace & Digital platform with goods / services traded by one seller. \\
\hline Digital ecosystem & A set of digital platforms with various goods and services. \\
\hline
\end{tabular}

The above approaches to the digital platforms classification have different grounds. In this regard, digital platforms referring to the education system are distinguished. So, for example, the following types of digital platforms [1, p.9] are considered in the research by Anakhov S.V. and Anakhov D.S.:

- social networks of scientists, suggesting communication (Academia, Scientists of Russia, SciPeople, etc.);

- open educational projects (Single point of access to educational resources, Moodle, Edison, etc.);

- open / virtual labs VirtuLab, PhET, Wolfram Demonstrations Project, IrYdium Chemistry Lab, "Virtual laboratory" teachmen.ru, Online Labs in, etc.);

- infrastructure platforms facilitating technological infrastructure leasing (World Community Grid, Kwipped, Ebay, GenTech, IVOA, Navitas, etc.);

- platforms for extended data transformation (Data.gov, Science.gov, etc.);

- crowdfunding platforms to raise research funds (Kickstarter, Medstarter, Funding Circle, etc.);

- open corporations / hackathons (Major Hacking League, Habr, Hackatons.rf, etc.);

- publishing and scientometric services to publish and rank scientific findings (Mendeley, eLibrary, "Istina", "Socionet", Cyberleninka, Google Academy, Scopus, Web of Science, AGRIS, ERIH, etc.);

- financial, registring and analytical platforms to organize contests and support scientific projects (RFBR, RSF, Innovation Promotion Foundation, Portal for supporting government orders of the Ministry of Education and Science, etc.).

Another criterion of the digital educational platforms classification is operation scale. Here, international educational platforms, national and local, both in the framework of one educational institution or consolidating several ones, can be distinguished.

Educational environment is developing in the same way as the RF economy and, in the authors' opinion, transition to a digital educational ecosystem flows naturally from the educational process improvement. It is the ecosystem-based higher education which becomes a logical extension of the higher education system development ensuring the 
targeted level of training quality for graduates, regardless of global challenges, which significantly impact the current state and perspective system development areas.

According to the authors, the digital educational ecosystem (ecosystem-based higher education) is a set of interconnected platforms consolidating students, higher educational institutions, employers, lending organizations and educational content, which provides for communications building and educational process improvement, considering market requirements and educational organizations' potential.

In the framework of the digital educational ecosystem, several blocks can be identified where universities are represented, employers with their proposals and requirements, normative documents regulating educational process and the activities of educational organizations, training materials, professional standards, banks with student loan programs, olympiads and other competitive events, revealing talented and promising applicants, able to develop in a given direction.

In the educational ecosystem, content availability is shaped by the needs and roles of each participant.

The first block is "banks, universities and olympiads". The target audience of this block is applicants. Here, they can easily learn about training programs, requirements and competitive events, which can add to the applicant's individual achievements. Another important point is to find out about bank lending terms to pay for tuition. Not all families can pay the full sum without borrowings, and in this block, applicants will consider the formal requirements, assess their chances, compare offers of various lending organizations and choose optimal terms.

The second block is "employer-university". In this block, communications are built between the employer and the higher educational institution, owing to which market challenges are identified and a competence model of a graduate is developed, with reference to standards and regulatory documents, formulating educational needs. As a result, a university graduate is a well-trained competitive specialist with the currently required knowledge and competencies.

The third block is "university-employer-student". In the framework of this block, communication links are built to ensure internship and further employment. In that way, successful students can gain valuable experience and prove effective for the potential further employment in the company after graduation.

Turning to digital resources operating in the Russian Federation, the following can be noted.

The nationa information system "Modern digital educational environment" has been launched, which provides various platforms and universities to learn online. By the 2020 results, the portal provided access to more than 1,850 online courses, 47 online learning platforms, 140 universities. During the operation period, more than $7 \mathrm{mln}$ training sessions by over one million people have been registered.[8]

For applicants in its turn, the "Online university enrollment" superservice has been launched. This service provides online application to the university without leaving home. To do this, applicants must attach copies of certain documents and send them to universities online. Moreover, the system itself will form an electronic application and track the resluts.

The issues of the higher education system digital transformation and platformization are in the focus of attention of government bodies. Thus, in March 2021, Deputy Prime Minister Chernyshenko D.N.[14] instructed the head of the Ministry of Science and Higher Education Falkov V.N. to introduce a new position of "Vice-Rector for Digitalization" in each university.

Previously, the ANO "Progressive Education Institute" proposed to introduce the position of IT Director (head teacher / Vice-Rector for digitalization) in educational 
institutions, whose main task would be to digitalize the educational process. A letter with this initiative was sent to the heads of the Ministry of Education of the Russian Federation, the Ministry of Science and Higher Education, as well as the Ministry of Digital Development, Communications and Mass Media of the Russian Federation.

However, in February 2021, the Ministry of Science and Higher Education of the Russian Federation did not support this initiative.

As part of the plan, higher educational institutions are developing digital development programs, where the main target implementation indicator is the introduction of educational programs with e-learning and distance learning technologies.

It is important to note that in 2020, 44 universities under the authority of the Ministry of Science and Higher Education of the Russian Federation have developed digital development programs and received relevant support, and in 2021 over 90 universities are expected to join the initiative. Starting from 2022, it will be implemented in the context of the federal project "Developing infrastructure for research and training" of the "Science and universities" national project, on a competitive basis, as grants for the digital development programs [8] implementation.

In the authors' view, platform education should not substitute the traditional form of education, but serve as an additional platform to provide educational services, which will contribute to increasing economic efficiency of an educational organization. Both training formats are not contending; on the contrary, they ensure the pedagogical tools expansion to improve the training process development.

On the one hand, platform-based education ensures receiving educational services, regardless of the location, developing personalized learning mode, considering the needs and interests of a particular student, which will provide for the graduates' professional fulfilment. However, like any other field of activity, the higher education platform and ecosystem models development can encounter certain risks.

First, decreasing training quality and student motivation.

Second, teaching staff layoff with a subsequent decrease in the scientific potential of the educational institution.

Third, absence of a unified digital educational platform leads to the educational platforms and contents differentiation at the educational institution level.

Fourth, a shift away from the traditional classes format and a reduction of live communication between a student and a teacher.

At the same time, the successful implementation of platform education directly depends on the response to the identified risks and changes in the external environment.

\section{Conclusions}

As a result, the authors proposed a specific approach to the categories of "digital educational platform" and "digital educational ecosystem (ecosystem-based higher education)", arranged a system of the digital platforms classification criteria on various grounds, and added the "operation scale" criterion to the digital educational platforms classification. Also, the current state of the educational services market is considered, the latest innovations in digital educational services are reviewed and risks of platform and ecosystem models of higher education development are revealed. Although the transition to digital space is inevitable, it is necessary to do the best to maintain education quality and ensure comfortable conditions of educational services provision, both in digital and analog formats. 


\section{References}

1. S. V. Anakhov, D. S. Anakhov, Digital platforms: aspects of development in the scientific and educational sphere, New inf. techn. in ed. and scien., 3, 6-15 (2020)

2. V. V. Aturin, I. S. Moga, S. M. Smagulova, Digital transformation management: scientific approaches and economic policy, Manag., 11 (2), 67-76 (2020)

3. I. Z. Geliskhanov, T. N. Yudina, A. V. Babkin, Digital platforms in the economy: essence, models, development trends, Sc. and tech. Stat. of SPbSPU. Econ. Scien. (2020). Access mode: https://economy.spbstu.ru/userfiles/files/articles/2018/6/02 Gelishanov-Yudina-Babkin.pdf

4. E. B. Dvoryadkina, E. G. Efimova, Spatial aspect of regional policy in the field of professional education system development, Manag., 10 (6), 28-41 (2019)

5. A. V. Keshelava, I. L. Khaet, The subject of digital economy and the role of digital tools, ANO "S.P. Kurdyumov Interdisciplinary Research Center "Sretensky Club" (2020). Access mode: http://spkurdyumov.ru /digital_economy/predmet-cifrovojekonomiki-i-rol-cifrovyx-instrumentov/

6. M. P. Loginov, N. V. Usova, Features of innovation management in the service sector, Bull.of Chel. St. Univ., 3 (425), 120-131 (2019)

7. M. Loginov, N. Usova, E. Nedorostkova, Ensuring sustainable development of higher education on the basis of digital educational services, SHS Web of Conferences, 106, 03014 (2021)

8. The Ministry of Education and Science does not support the introduction of the post of Vice-Rector for digitalization in universities, TASS News Agency. Access mode: https://tass.ru/obschestvo/10706393

9. Yu. G. Myslyakova, N. V. Usova, Digital transformation of educational services of universities in the context of global challenges: regional aspect, Publ. Admin. Elect.bull., 82, 326-353 (2020)

10. I. S. Naydenko, O. A. Velichko, Problems and prospects of the digital technologies introduction development in higher education, Hum. Scient. Bull., 5, 209-214 (2020)

11. E. V. Popova, A. I. Semenov, Analysis of digital platforms for the effective implementation of value chains, Innov. and invest., 8, 234-237 (2019)

12. E. N. Smirnov, Global digital platforms as a factor of the world markets transformation, Iss. of inn. Ec., 10 (1), 13-24 (2020)

13. Digital platforms approaches to definition and typification, ANO "Digital Economy" (2020). Access mode: https://files.data-economy.ru/digital_platforms.pdf

14. Chernyshenko instructed to create the post of Vice-Rector for digitalization in universities, TASS News Agency (2021). Access mode: https://tass.ru/obschestvo/10850315 